\title{
Hemocyte parameters of the Pacific oyster Crassostrea gigas a year after the Hebei Spirit oil spill off the west coast of Korea
}

\author{
Ludovic Donaghy $\cdot$ Hyun-Ki Hong $\cdot$ Hee-Jung Lee $\cdot$ \\ Je-Cheon Jun $\cdot$ Young-Je Park $\cdot$ Kwang-Sik Choi
}

Received: 8 June 2009 / Accepted: 7 January 2010 / Published online: 22 January 2010

(C) Springer-Verlag and AWI 2010

\begin{abstract}
In marine bivalves, hemocytes support various physiological functions, including immune defense, nutrient transport, shell repair, and homeostatic maintenance. Although the effects of marine contaminants on the immunological functions of bivalves have been extensively investigated, the impacts of oil spills are not well understood. Therefore, we investigated hemocyte parameters in the Pacific oyster Crassostrea gigas 13 months after the Hebei Spirit oil spill (December 2007) off the west coast of Korea. The parameters studied included hemocyte concentration and mortality, relative proportion of hemocyte populations, and immunological functions such as phagocytosis
\end{abstract}

Communicated by H.-D. Franke.

Submitted to Helgoland Marine Research.

L. Donaghy $\cdot$ H.-K. Hong · H.-J. Lee $\cdot$ K.-S. Choi $(\square)$

School of Applied Marine Sciences (POST BK-21)

and Marine and Environmental Research Institute,

Cheju National University, 66 Jejudaehakno,

Jeju 690-756, Republic of Korea

e-mail: skchoi@cheju.ac.kr

J.-C. Jun

West Fisheries Research Institute,

National Fisheries Research and Development Institute (NFRDI), Incheon, Republic of Korea

Y.-J. Park

Tidal Flat Research Institute,

National Fisheries Research and Development Institute (NFRDI),

Kunsan, Republic of Korea

Present Address:

L. Donaghy

LEMAR CNRS UMR 6539, IUEM,

Université de Bretagne Occidentale, Place Nicolas Copernic,

29280 Technopôle Brest-Iroise, Plouzané, France and oxidative activity using flow cytometry. These immune-related parameters in oysters damaged by the oil spill were also compared to control oysters that were collected from an area unaffected by the spill. The flow cytometry study indicated that granulocyte population, phagocytic capacity, and reactive oxygen species production in oysters exposed to crude oil 13 months prior were depressed compared to the unexposed control oysters. Our data suggest that immunocompetence in oysters affected by the oil spill had not fully recovered 1 year after the accident, although more detailed studies on the physiology and disease resistance should be performed.

Keywords Immunological parameters · Oil spill · Crassostrea gigas $\cdot$ Hemocytes $\cdot$ Pollution $\cdot$ Hebei Spirit

\section{Introduction}

The internal responses of marine bivalves to invasive pathogens, natural environmental impacts, and pollutants are mediated at least in part by hemocytes (Auffret 1988; for review see Hine 1999). Bivalve hemocytes are classified into two main classes based on their morphologies, granulocytes and agranulocytes, the latter of which are also called hyalinocytes (Cheng 1981). Hemocytes act as cellular immune effectors through their capacities to phagocytize, encapsulate, and subsequently degrade invading foreign materials (Montes et al. 1995; Chu 2000; Canesi et al. 2002). Hemocytes express various hydrolytic enzymes and are able to produce reactive oxygen species (ROS), both of which are involved in the destruction of ingested or encapsulating nonself materials (Adema et al. 1991; Toreilles et al. 1996; López et al. 1997; Cima et al. 2000; Bayne et al. 2001; Lambert et al. 2003; Terahara and Takahashi 
2008). Hemocytes are also involved in other vital functions of bivalve biology and physiology, including nutrient transport and digestion, shell and tissue formation, and repair, as well as homeostatic maintenance (Cheng 1996, 2000; Chu 2000; Beninger et al. 2003; Mount et al. 2004).

Numerous studies have studied the effects of contaminants on marine bivalve immunology. For example, many investigations have evaluated the release of metals into aquatic systems because of the high threat to human health (Larson et al. 1989; Fisher et al. 2000; Fournier et al. 2001; Matozzo et al. 2001; Oliver et al. 2001, 2003; Gagnaire et al. 2004; Parry and Pipe 2004). Although organic pollutants have received less attention, polycyclic aromatic hydrocarbons (PAHs), which are constituents of crude oil, have been reported to alter hemocyte function in marine bivalves. For example, PAH exposure was found to inhibit phagocytic activity in the clam Mya arenaria (Fournier et al. 2002, 2007) and the Pacific oyster Crassostrea gigas (Bado-Nilles et al. 2008).

On the morning of December 7, 2007, a crane-carrying barge hit the Hong Kong-registered crude oil carrier Hebei Spirit, which was anchored approximately $8 \mathrm{~km}$ off Taean on the west coast of Korea (Fig. 1). The collision punctured three of five oil tanks, resulting in the leaking of approximately 10,500 tons of crude oil into the sea (UNOCHA 2007; ITOPF 2008). This oil spill was about one-third the size of the Exxon Valdez oil spill and the worst oil spill to have ever occurred on Korean shores. The region affected by the oil is one of Asia's largest wetland areas within a national park and this area had also been leased for the farming of shellfish such as oysters, abalones, and clams (UNOCHA 2007).

Despite the considerable impacts that crude oil contamination is known to have on the physiology of marine animals, little is known about the detrimental effects of crude oil on marine bivalve physiology, particularly with respect to hemocyte function. In January 2009, 13 months after the Hebei Spirit incident, we analyzed hemocyte parameters in Pacific oysters exposed to the crude oil to evaluate their physiological condition. In this study, we compared the hemocyte parameters of the oysters affected by the oil spill to the parameters of healthy oysters collected from an area that was not affected by the spill.

\section{Materials and methods}

Sampling effort

In January 2009, oysters were collected from an oyster farm located at Uihangri beach in Taean, one of the major areas damaged by the oil spill $\left(36^{\circ} 50^{\prime} 2.46^{\prime \prime} \mathrm{N}, 126^{\circ} 9^{\prime} 15.88^{\prime \prime} \mathrm{E}\right)$ and Daebudo Island in Incheon Bay $\left(37^{\circ} 15^{\prime} 9.96^{\prime \prime} \mathrm{N}\right.$, $126^{\circ} 30^{\prime} 48.09^{\prime \prime} \mathrm{E}$ ), which was a control site unaffected by damage from the Hebei Spirit oil spill (Fig. 1). The oysters were transferred to the laboratory and a notch was ground into the anterior end of the shell. Notched oysters were then placed into a tank for at least $48 \mathrm{~h}$ prior to analyses to acclimate to the laboratory and recover from the stress induced from grinding the notch.

\section{Analyses of hemocyte parameters}

Hemolymph from each oyster was withdrawn through the previously ground notch, immediately filtered through an $80-\mu \mathrm{m}$ nylon mesh, and individually transferred into microtubes maintained on ice to minimize cell clumping. Hemolymph from five oysters was pooled into one tube for the flow cytometry analysis. Six replicates were prepared from each sampling location.

All hemocyte parameters were analyzed using a FACS Calibur flow cytometer (Becton and Dickinson) and the protocols were adapted from Delaporte et al. (2003) and Hégaret et al. (2003a, b). Hemocyte proportions and other cytometric measurements (i.e., size and internal complexity) of each hemocyte population were determined on SYBR Green I-positive cells (final dilution $=10 \times$ ). Cell mortality was assessed using the propidium iodide exclusion
Fig. 1 Location map of C. gigas sampling sites. (1) Overview of Far East Asia. (2) Map of Korea displaying the location of the Hebei Spirit oil-spill accident and resulting broad heavy oiling (dark-gray area), localized heavy oiling, and scattered tar balls (light-gray area). (3) Close-up of Pacific oyster sampling sites. Oil spill-affected Pacific oysters were collected in Taean County (a), whereas unaffected oysters came from Sunjaedo Island in Incheon Bay (b)

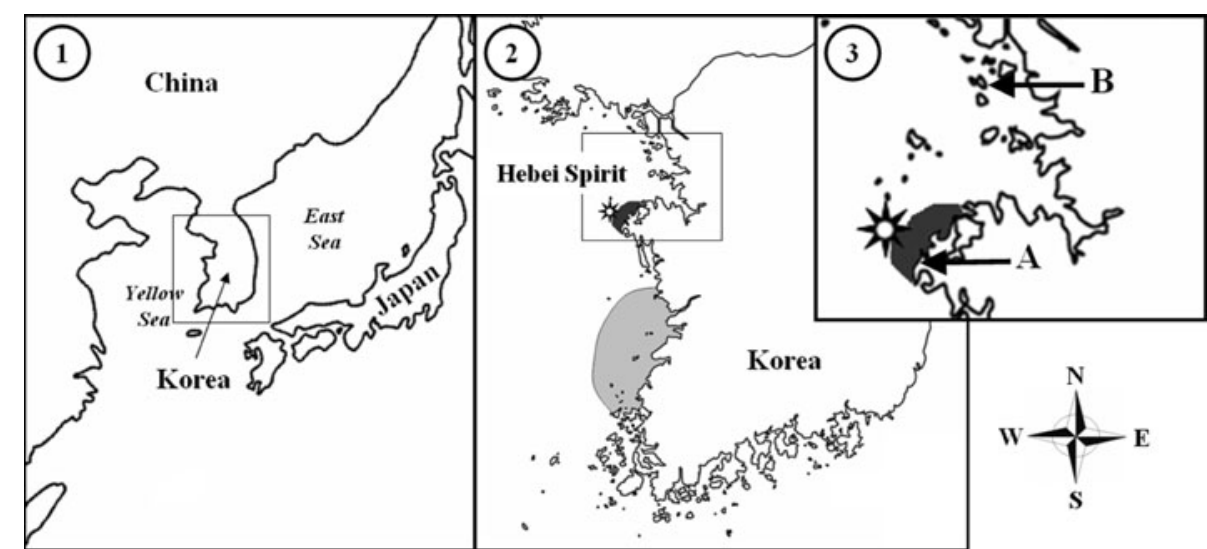


method (final concentration $=20 \mu \mathrm{g} \mathrm{ml}^{-1}$ ). Phagocytic capacity was measured by incubating the oyster hemocytes with $2.0-\mu \mathrm{m}$ fluorescent beads and determining the percentage of cells that engulfed three or more beads. ROS production was evaluated through the oxidation of dichlorofluorescein diacetate (DCFH-DA) into the fluorescent DCF probe. The oxidative activity of hemocytes was proportional to the emitted fluorescence and expressed in flow cytometry arbitrary units (A.U.).

\section{Statistical analysis}

The hemocyte parameters were compared between the oysters collected from the Hebei Spirit oil spill site and the oysters collected from the unaffected control site at Incheon Bay using a one-way analysis of variance (ANOVA) in SAS.

\section{Results}

Cytometric measurements and the proportion of each hemocyte population are summarized in Table 1. Flow cytometry methods enable the discrimination between hemocyte subtypes using morphological parameters such as size and internal complexity. Internal complexity was reported as granularity and relied on several inner components of the cells, including the shape of the nucleus, the amount and type of cytoplasmic granules, cytoplasmic inclusions resulting from ingestion of foreign materials, and membrane roughness. The flow cytometry analysis indicated three morphologically distinguishable hemocyte populations (Fig. 2) in oysters from both locations: granulocytes, hyalinocytes, and blast-like cells. Granulocytes were determined to be the largest cells at both the spill and control sites (167.8 and 164.3 A.U., respectively) and displayed the highest internal complexity (146.7 and 149.4 A.U., respectively). Hyalinocytes were smaller in size (112.2 and 126.1 A.U., respectively) than the granulocytes and had a low internal complexity (13.4 and 15.7

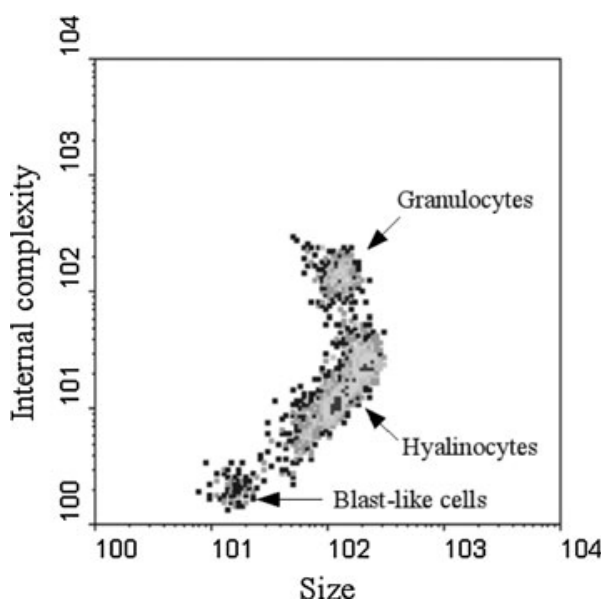

Fig. 2 Pacific oyster hemocyte populations. Flow cytometric density plot representation of $C$. gigas hemocytes by size versus internal complexity parameters

A.U., respectively), whereas blast-like cells were very small (20.3 and 18.2 A.U., respectively) and exhibited the lowest internal complexity (2.3 A.U. in both locations). For both sites, hyalinocytes were the most numerous hemocytes (77.2 and $79 \%$, respectively). Blast-like cells were the more numerous in the hemolymph of oysters from the spill site (14.7\%) compared to oysters from the control site (10.7\%). In contrast, oysters from the spill site contained less granulocytes $(4.2 \%)$ than the control oysters $(8.7 \%)$. However, the proportions and cytometric characteristics of the hemocyte populations were not significantly different in oysters from the spill and control sites.

The concentration and mortality of circulating hemocytes, as well as their phagocytic capacity and ROS production, are summarized in Table 2. The concentration of hemocytes in the hemolymph was similar among the two oyster populations $\left(324,949 \pm 155,651\right.$ cells ml ${ }^{-1}$ for the spill site and 401,201 $\pm 221,898$ cells ml $^{-1}$ for the control site). Hemocyte mortality was low in oysters from both the control site (5.5\%) and the spill site (5.9\%). Furthermore, the hemocyte concentration and mortality in the two oyster populations were not statistically different.

Table 1 Proportion and cytometric measurements of hemocyte populations

\begin{tabular}{|c|c|c|c|c|c|c|}
\hline & \multicolumn{2}{|l|}{ Percentage } & \multicolumn{2}{|l|}{ Size } & \multicolumn{2}{|c|}{ Internal complexity } \\
\hline & $\begin{array}{l}\text { Oil spill } \\
\text { damaged area }\end{array}$ & $\begin{array}{l}\text { Control site } \\
\text { (Incheon) }\end{array}$ & $\begin{array}{l}\text { Oil spill } \\
\text { damaged area }\end{array}$ & $\begin{array}{l}\text { Control site } \\
\text { (Incheon) }\end{array}$ & $\begin{array}{l}\text { Oil spill } \\
\text { damaged area }\end{array}$ & $\begin{array}{l}\text { Control site } \\
\text { (Incheon) }\end{array}$ \\
\hline GR & $4.2 \pm 2.7$ & $8.7 \pm 7.0$ & $167.8 \pm 24.1$ & $164.3 \pm 15.5$ & $146.7 \pm 20.3$ & $149.4 \pm 13.8$ \\
\hline Hy & $77.2 \pm 7.4$ & $79.0 \pm 5.6$ & $112.2 \pm 25.7$ & $126.1 \pm 20.8$ & $13.4 \pm 3.4$ & $15.7 \pm 3.1$ \\
\hline $\mathrm{BL}$ & $14.7 \pm 7.0$ & $10.7 \pm 5.8$ & $20.3 \pm 1.5$ & $18.2 \pm 0.8$ & $2.3 \pm 0.3$ & $2.3 \pm 0.1$ \\
\hline
\end{tabular}

The proportion of each hemocyte population, size, and internal complexity were determined on SYBR Green I-positive cells. Size and internal complexity of hemocytes are expressed in flow cytometric arbitrary units (A.U.). $G r$ granulocytes, $H y$ hyalinocytes, $B L$ blast-like cells. Values are reported as the mean $\pm \mathrm{SD}$. All differences were nonsignificant (ANOVA) 
Table 2 Concentration of hemocytes, mortality, phagocytic capacity, and ROS production

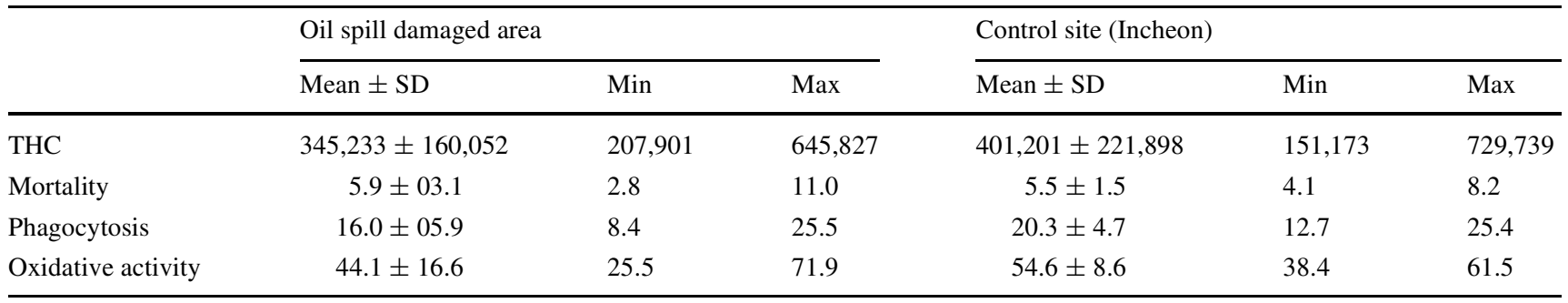

Total hemocyte count (THC) was determined on SYBR Green I-positive cells. THC is expressed as the number of hemocytes per milliliter. Hemocyte mortality is the percentage of propidium iodide-positive hemocytes. Phagocytic capacity is reported as the percentage of hemocytes having engulfed three or more fluorescent beads. Oxidative activity was evaluated through the production of reactive oxygen species and expressed in flow cytometric arbitrary units (A.U.). All differences were nonsignificant (ANOVA)

As shown in Table 2, the phagocytic capacity (i.e., hemocytes that engulfed three or more fluorescent beads) of oysters from the spill site was $16.0 \pm 5.9 \%$, whereas that of oysters from the control site was greater at $20.3 \pm 4.7 \%$. The mean production of ROS was lower in oysters from the damaged area (44.1 A.U.) than in those from the control site (54.6 A.U.). Although the phagocytic capacity and ROS production of oysters from the control site were somewhat higher than the values determined in oysters from the spill site, the differences were not significant.

\section{Discussion}

As summarized in Table 1, the control and oil spill-damaged oysters displayed a dissimilar proportion of granulocytes and blast-like cells, but not hyalinocytes. That is, the concentration of granulocytes was twice lower in the oilexposed oysters than in the control oysters. Due to their high phagocytic capacities, granulocytes might have been the hemocytes most affected by the ingestion of toxic components resulting from the oil spill. These toxins might have induced intracellular disturbances and DNA damage, such as strand breaks and cross-links or mutations, resulting in dysfunctional granulocytes or granulocyte apoptosis (Dixon et al. 1985; Nacci et al. 1992; Telford et al. 1992; Vukmirović et al. 1994; Walker and Sikorska 1997; Blaise et al. 2002; Hamoutene et al. 2002; Bolognesi et al. 2004; Rocher et al. 2006; Gagné et al. 2008). In contrast, the oil spill-damaged oysters exhibited more blast-like cells than the control oysters (14.7 vs. 10.7\%, respectively). Blast-like cells are very small agranular cells that are considered stem cells freely circulating in the hemolymph (Cima et al. 2000; Aladaileh et al. 2007; Matozzo et al. 2008; Travers et al. 2008; Donaghy et al. 2010). Although current knowledge about hemopoiesis in marine bivalves is somewhat limited (Hine 1999; Matozzo et al. 2008), multiplication of blastlike cells might have been initiated to mainly restore the decreased granulocyte population. The long-term effects of the oil pollution should be further analyzed by determining the DNA content and cell cycle of circulating hemocytes.

The flow cytometric analyses performed 13 months after the Hebei Spirit incident in this study indicated that Pacific oysters from the spill site were less immunocompetent compared to oysters from the control site. Numerous studies have reported that granulocytes are the main population of hemocytes involved in phagocytosis and ROS production in marine bivalves, although hyalinocytes might exhibit similar phagocytic and oxidative activities (Tripp 1992; Cima et al. 2000; Delaporte et al. 2003; Goedken and De Guise 2004; Lambert et al. 2007; Donaghy et al. 2010). Whole hemocytes of oysters from the spill site exhibited a lower total phagocytic activity and lower ROS production than the control oysters (Table 2). Although these differences might partly be attributable to the lower phagocytic and oxidative activities of the granulocytes, this reduced immunocompetence probably results mainly from the lower granulocyte proportion in the hemolymph of the oysters from the spill site (4.2 and $8.7 \%$, respectively).

Few studies have examined the impact of oil spills on marine bivalve hemocytes, and fewer have evaluated the Pacific oysters affected by the Hebei Spirit oil spill. However, we assumed that the hemocyte parameters were likely dramatically altered immediately after the oil spill, although we did not test the immediate effects in this investigation. Other studies have shown that severe immunosuppression, including a reduction in superoxide anion generation and phagocytic activity, occurred in the mussel Mytilus edulis following the Sea Empress oil spill off the coast of Wales, UK during the first month following the incident (Dyrynda et al. 2000). According to Gagnaire et al. (2006) and Bado-Nilles et al. (2008), PAHs altered the hemocyte parameters in $C$. gigas as soon as $4 \mathrm{~h}$ postexposure.

Several studies have reported that the short- and longterm impacts of oil-spill pollution on immunological activities of marine bivalve hemocytes are difficult to predict because numerous internal and external parameters govern 
such activities. After the Prestige oil spill off the Galician coast of Spain in 2002, Novas et al. (2007) reported a longterm alteration of hemocyte-related immune parameters in the mussel Mytilus galloprovincialis, including a decrease in nitric oxide production and an increased sensitivity of hemocytes to apoptosis and necrosis. In contrast, Ordás et al. (2007) did not observe an effect of the fuel oil spilled by the Prestige on hemocyte immune parameters when $M$. galloprovincialis was maintained in an aquarium and exposed to the fuel oil for 4 months. In addition, more than 1 year after the Erika oil spill occurred off Pointe de Penmarc'h, Southern Brittany, France, in 1999, severe immunological alteration was detected in C. gigas in only one of the numerous damaged sites (Auffret et al. 2004).

Environmental surveys conducted within the oil-spill areas a few days after the accident revealed that oil contaminant levels in marine bivalve tissues were 10-1,000 times higher than pre-spill levels (Ministry of Land, Transport and Maritime Affairs of Korea, MLTM 2008). However, residual oil concentrations in shellfish tissues dropped dramatically 10 months after the incident, possibly due to the large cleanup efforts along the damaged shores. Consequently, the survey conducted in October 2008 indicated that the levels of oil contaminants in the Taean oil-spill sites were similar to the pre-oil-spill level. However, the survey results indicated that residual oil contaminants in shellfish tissues in some heavily damaged areas, including the present study site, remained relatively high 1 year after the accident (MLTM 2008). The comparatively low levels of immune parameters such as granulocyte population, rate of phagocytosis, and oxidative activity observed in oysters from the spill area in this study suggest that these oysters continue to undergo stress from the accumulation of oil components in their body. Note that this study site was one of the most heavily damaged oil-spill areas.

Unlike other oyster farms located on the southern coast of Korea, in which oysters are raised using submergedlongline suspended culture systems, oysters from the Taean oil-spill area are cultivated using a rack culture system installed within the lower intertidal area. To harvest oyster spats for the culture, numerous empty adult oyster shells are attached to a 2-3-m-long string and suspended on the rack system. Oyster spats may settle on the spat collectors in July and August, and they are harvested 1.5-2 years after the grow-out period. These suspended rack-culture systems used in the Taean area could have been advantageous to oysters in the early phase after the oil-spill accident because the oysters could have avoided direct exposure to oil-contaminated seawater during low tide. According to a report by the MLTM (2008), PAHs in the water column soon after the incident were very high, up to $5,170 \mathrm{ng} \mathrm{L}^{-1}$. However, PAH levels in the water column dropped dramatically to between 9.8 and $65.8 \mathrm{ng} \mathrm{L}^{-1}$ only 1 month after the accident.
This rapid decrease in water column PAHs was also reported in the Exxon Valdez oil spill (Boehm et al. 2007). Consequently, a fast reduction in oil contaminants in the water column combined with the rack-suspended culture system in the intertidal area probably contributed greatly in helping oysters recover from stresses due to the oil spill during the past 13 months.

In conclusion, we compared the immune parameters of oysters collected from Uihangri beach, one of the most heavily exposed areas to the spilled oil, with immune parameters of control oysters from Daebudo in Incheon Bay. A 13 months after the Hebei Spirit oil spill, the oysters from the most heavily contaminated beach had not fully recovered their hemocyte capabilities. The observed reduction in immunocompetence among oysters from the contaminated area is probably due to their lower granulocyte content. Long-term monitoring of their immune capacities and disease resistance should be performed to assess whether the oil spill-affected Pacific oysters will fully recover their immune response.

Acknowledgments We would like to thank the staff of the Shellfish Aquaculture and Research Laboratory at Cheju National University for their help in data acquisition. This study was in part supported by a funding from the Korea Ministry of Agriculture, Forestry, Fisheries and Food through a project, "2008 Studies on the Restoration of the Fishing Ground in Taean Oil Spill Area".

\section{References}

Adema CM, Van Der Knaap WPW, Sminia T (1991) Molluscan hemocyte-mediated cytotoxicity: the role of reactive oxygen intermediates. Rev Aquat Sci 4:201-223

Aladaileh S, Nair SV, Birch D, Raftos DA (2007) Sydney rock oyster (Saccostrea glomerata) hemocytes: morphology and function. J Invertebr Pathol 96:48-63

Auffret M (1988) Bivalve hemocyte morphology. Am Fish Soc Spec Pub 18:169-177

Auffret M, Duchemin M, Rousseau S, Boutet I, Tanguy A, Moraga D, Marhic A (2004) Monitoring of immunotoxic responses in oysters reared in areas contaminated by the "Erika" oil spill. Aquat Living Resour 17:297-302

Bado-Nilles A, Gagnaire B, Thomas-Guyon H, Le Floch S, Renault T (2008) Effects of 16 pure hydrocarbons and two oils on haemocyte and haemolymphatic parameters in the Pacific oyster, Crassostrea gigas (Thunberg). Toxicol Vitro 22:1610-1617

Bayne CJ, Hahn UK, Bender RC (2001) Mechanisms of molluscan host resistance and of parasite strategies for survival. Parasitol 123:S159-S167

Beninger PG, Le Pennec G, Le Pennec M (2003) Demonstration of nutrient pathway from the digestive system to oocytes in the gonad intestinal loop of the scallop Pecten maximus L. Biol Bull 205:83-92

Blaise C, Gagné F, Pellerin J, Hansen PD, Trottier S (2002) Molluscan shellfish biomarker study of the Quebec, Canada, Saguenay Fjord with the soft-shell calm, Mya arenaria. Environ Toxicol 17:170186

Boehm PD, Neff JM, Page DS (2007) Assessment of polycyclic aromatic hydrocarbon exposure in the waters of Prince William 
Sound after the Exxon Valdez oil spill: 1989-2005. Mar Poll Bull 54:339-356

Bolognesi C, Frenzilli G, Lasagna C, Perrone E, Roggieri P (2004) Genotoxicity biomarkers in Mytilus galloprovincialis: wild versus caged mussels. Mut Res 552:153-162

Canesi L, Gallo G, Gavioloi M, Pruzzo C (2002) Bacteria-hemocyte interactions and phagocytosis in marine bivalves. Microsc Res Tech 57:469-476

Cheng TC (1981) Bivalves. In: Ratcliff NA, Rowley AF (eds) Invertebrate blood cells. Academic Press, London, pp 233-300

Cheng TC (1996) Hemocytes: forms and functions. In: Kennedy VS, Newell RIE, Eble AF (eds) The eastern oyster Crassostrea virginica. Maryland Sea Grant Book, College Park, pp 299-333

Cheng TC (2000) Cellular defense mechanisms in oysters. In: Fingerman N, Nagabhushanam R (eds) Recent advances in marine biotechnology. Immuno-biology and pathology. Science Publishers, Enfield, pp 43-83

Chu FLE (2000) Defense mechanisms of marine bivalves. In: Fingerman N, Nagabhushanam R (eds) Recent advances in marine biotechnology. Immuno-biology and pathology. Science Publishers, Enfield, pp 1-42

Cima F, Matozzo V, Marin MG, Ballarin L (2000) Haemocytes of the clam Tapes philippinarum (Adams \& Reeve, 1850): morphofunctional characterisation. Fish Shellfish Immunol 10:677-693

Delaporte M, Soudant P, Moal J, Lambert C, Quéré C, Miner P, Choquet G, Paillard C, Samain JF (2003) Effect of mono-specific algal diet on immune functions in two bivalve species-Crassostrea gigas and Ruditapes philippinarum. J Exp Biol 206:3053-3064

Dixon DR, Jones M, Harrison FL (1985) Cytogenic evidence of inducible processes linked with metabolism of a xenobiotic chemical in adult and larval Mytilus edulis. Sci Total Environ 46:1-8

Donaghy L, Kim BK, Hong HK, Choi KS (2010) Flow cytometry studies on the populations and immune parameters of the hemocytes of the Suminoe oyster, Crassostrea ariakensis. Fish Shellfish Immunol Accepted Manuscript, (in press)

Dyrynda EA, Law RJ, Dyrynda PEJ, Kelly CA, Pipe RK, Ratcliffe NA (2000) Changes in immune parameters of natural mussel Mytilus edulis populations following a major oil spill ('Sea Empress', Wales, UK). Mar Ecol Progr 206:155-170

Fisher WS, Oliver LM, Winstead JT, Long ER (2000) A survey of oysters Crassostrea virginica from Tampa Bay, Florida: associations of internal defense measurements with contaminant burdens. Aquat Toxicol 51:115-138

Fournier M, Pellerin J, Clermont Y, Morin Y, Brousseau P (2001) Effects of in vivo exposure of Mya arenaria to organic and inorganic mercury on phagocytic activity of hemocytes. Toxicology 161:201-211

Fournier M, Pellerin J, Lebeuf M, Brousseau P, Morin Y, Cyr D (2002) Effects of exposure of Mya arenaria and Mactromeris polynyma to contaminated marine sediments on phagocytic activity of hemocytes. Aquat Toxicol 59:83-92

Gagnaire B, Thomas-Guyon H, Renault T (2004) In vitro effects of cadmium and mercury on Pacific oyster, Crassostrea gigas (Thunberg), haemocytes. Fish Shellfish Immunol 16:501-512

Gagnaire B, Thomas-Guyon H, Burgeot T, Renault T (2006) Pollutant effects on Pacific oyster, Crassostrea gigas (Thunberg), hemocytes: screening of 23 molecules using flow cytometry. Cell Biol Toxicol 22:1-14

Gagné F, Blaise C, Pellerin J, Fournier M, Durand MJ, Talbot A (2008) Relationships between intertidal clam population and health status of the soft-shell clam Mya arenaria in the St. Lawrence Estuary and Saguenay Fjord (Québec, Canada). Environ Internat 34:30-43

Goedken M, De Guise S (2004) Flow cytometry as a tool to quantify oyster defence mechanisms. Fish Shellfish Immunol 16:539-552
Hamoutene D, Payne JF, Rahimtula A, Lee K (2002) Use of the Comet assay to assess DNA damage in hemocytes and digestive gland cells of mussels and clams exposed to water contaminated with petroleum hydrocarbons. Mar Environ Res 54:471-474

Hégaret H, Wikfors GH, Soudant P (2003a) Flow-cytometric analysis of haemocytes from eastern oysters, Crassostrea virginica, subjected to a sudden temperature elevation: I. Haemocyte types and morphology. J Exp Mar Biol Ecol 293:237-248

Hégaret H, Wikfors GH, Soudant P (2003b) Flow cytometric analysis of haemocytes from eastern oysters, Crassostrea virginica, subjected to a sudden temperature elevation: II. Haemocyte functions: aggregation, viability, phagocytosis, and respiratory burst. J Exp Mar Biol Ecol 293:249-265

Hine PM (1999) The inter-relationships of bivalve haemocytes. Fish Shellfish Immunol 9:367-385

ITOPF (International Tanker Owners Pollution Federation) (2008) The environmental impact of the Hebei Spirit oil spill, Taean, South Korea (7th December 2007). http://www.itopf.com/news-andevents/archive/2008.html\#HBoil. Accessed 9 Feb 2009

Lambert C, Soudant P, Choquet G, Paillard C (2003) Measurement of Crassostrea gigas haemocyte oxidative metabolism by flow cytometry and the inhibiting capacity of pathogenic vibrios. Fish Shellfish Immunol 15:225-240

Lambert C, Soudant P, Jegaden M, Delaporte M, Labreuche Y, Moal J, Samain JF (2007) In vitro modulation of reactive oxygen and nitrogen intermediate (ROI/RNI) production in Crassostrea gigas hemocytes. Aquaculture 270:413-421

Larson KG, Robertson BS, Hetrick FM (1989) Effect of environmental pollutants on the chemiluminescence of haemocytes from the American oyster Crassostrea virginica. Dis Aquat Org 6:131136

López C, Carballal MJ, Azevedo C, Villalba A (1997) Enzyme characterisation of the circulating haemocytes of the carpet shell clam Ruditapes decussatus (mollusca:Bivalvia). Fish Shellfish Immunol 7:595-608

Matozzo V, Ballarin L, Pampanin M, Marin MG (2001) Effects of copper and cadmium exposure on functional responses of hemocytes in the clam, Tapes philippinarum. Arch Environ Contam Toxicol 41:163-170

Matozzo V, Marin MG, Cima F, Ballarin L (2008) First evidence of cell division in circulating haemocytes from the manila clam Tapes philippinarum. Cell Biol Int 32:865-868

Ministry of Land, Transport and Maritime Affairs of Korea (MLTM) (2008) Environmental impact assessment of the Hebei Spirit oil spill. MLTM report number 11-1611000-000392-01 (in Korean with English summary)

Montes JF, Mercè D, Garcia-Valero J (1995) Cellular defense mechanism of the clam Tapes semidecussatus against infection by the protozoan Perkinsus sp. Cell Tissue Res 279:529-538

Mount AS, Wheeler AP, Paradkar RP, Snider D (2004) Hemocytemediated shell mineralization in the Eastern Oyster. Science 304:297-300

Nacci D, Nelson S, Nelson W, Jackim E (1992) Application of the DNA alkaline unwinding assay to detect DNA strand breaks in marine bivalves. Mar Environ Res 33:83-100

Novas A, Barcia R, Ramos-Martínez JI (2007) After the prestige oil spill modifications in NO production and other parameters related to the immune response were detected in hemocytes of Mytilus galloprovincialis. Aquat Toxicol 85:285-290

Oliver LM, Fisher WS, Winstead JT, Hemmer BL, Long ER (2001) Relationships between tissue contaminants and defense-related characteristics of oysters (Crassostrea virginica) from five Florida bays. Aquat Toxicol 55:203-222

Oliver LM, Fisher WS, Volety AK, Malaeb Z (2003) Greater hemocyte bactericidal activity in oysters (Crassostrea virginica) from a 
relatively contaminated site in Pensacola Bay, Florida. Aquat Toxicol 64:363-373

Ordás MC, Albaigés J, Batona JM, Ordás A, Figueras A (2007) Assessment of in vitro effects of the Prestige fuel oil spill on the Mediterranean mussel immune system. Arch Environ Contam Toxicol 52:200-206

Parry HE, Pipe RK (2004) Interactive effects of temperature and copper on immunocompetence and disease susceptibility in mussels (Mytilus edulis). Aquat Toxicol 69:311-325

Rocher B, Le Goff J, Peluhet L, Briand M, Manduzio H, Gallois J, Devier MH, Geffard O, Gricourt L, Augagneur S, Budzinski H, Pottier D, Andre V, Lebailly P, Cachot J (2006) Genotoxicant accumulation and cellular defence activation in bivalves chronically exposed to waterborne contaminants from the Seine River. Aquat Toxicol 79:65-77

Telford WG, King LE, Fraker PJ (1992) Comparative evaluation of several DNA binding dyes in the detection of apoptosis-associated chromatin degradation by flow cytometry. Cytometry 13:137-143

Terahara K, Takahashi KG (2008) Mechanisms and immunological roles of apoptosis in molluscs. Curr Pharmaceut Des 14:131-137
Toreilles J, Guérin MC, Roch P (1996) Reactive oxygen species and defense mechanisms in marine bivalves. Compt Rendus Acad Sci III Sci Vie 319:209-218 in French

Travers MA, da Silva PM, Le Goïc N, Marie D, Donval A, Huchette S, Paillard C, Koken M (2008) Morphologic, cytometric and functional characterization of abalone (Haliotis tuberculata) haemocytes. Fish Shellfish Immunol 24:400-411

Tripp MR (1992) Phagocytosis by hemocytes of the hard clam, Mercenaria mercenaria. J Invertebr Pathol 59:222-227

UNOCHA (United Nations Office for the Coordination of Humanitarian Affairs) (2007) Hebei spirit oil spill-Republic of Korea, situation report no. 2. (2007/12/17) http://ochaonline.un.org/News/ OCHANewsCentre/2009SituationReports/2007/tabid/1332/language/en-US/Default.aspx. Accessed 9 Feb 2009

Vukmirović M, Bihari N, Zahn RK, Müller WEG, Batel R (1994) DNA damage in marine mussel Mytilus galloprovincialis as a biomarker of environmental contamination. Mar Ecol Progr 190:165-171

Walker PR, Sikorska M (1997) New aspects of the mechanism of DNA fragmentation in apoptosis. Biochem Cell Biol 75:287-299 